\title{
First records of Puccinia bornmuelleri (Pucciniales) in Ukraine
}

\author{
Yuri Ya. TYKHONENKO, Vera P. HAYOVA \\ M.G. Kholodny Institute of Botany, National Academy of Sciences of Ukraine \\ 2 Tereshchenkivska Str., Kyiv 01004, Ukraine \\ yu.ya.tykhonenko@gmail.com
}

Tykhonenko Yu.Ya., Hayova V.P. 2019. First records of Puccinia bornmuelleri (Pucciniales) in Ukraine. Ukrainian Botanical Journal, 76(5): 445-450.

Abstract. A new for Ukraine rust fungus Puccinia bornmuelleri was recorded on Levisticum officinale in garden plots of two villages in Kyiv Region, Ukraine in June 2019. This fungus was first collected by J. Bornmüller in Iran in 1892 and described by P. Magnus in 1899. Until the end of the $20^{\text {th }}$ century the species has been reported exclusively from Iran and Afghanistan, but from 2000 onwards it has been found in several countries in Central Europe. By now P. bornmuelleri is known in Austria, the Czech Republic, Finland, Germany, Hungary, the Netherlands, Poland, Romania and Ukraine (current report). The recent spread of this fungus in Europe may have been accelerated by the ongoing climate change. Data on restricted distribution of $P$. bornmuelleri before the $21^{\text {st }}$ century give evidence in favor of the hypothesis that the natural range of $L$. officinale is confined to Iran and Afghanistan. Examination by SEM revealed that echinulations of the wall surface of urediniospores are restricted mainly to their apical parts. In addition to already known phenological data, freshly emerged spermogonia and primary uredinia were observed in the first decade of September on the late summer offshoots of lovage. This phenomenon implies the possibility of teliospores germination without overwintering since spermogonia can only originate from basidiospores infection. The article is illustrated by original micrographs obtained using light and scanning electron microscopy.

Keywords: distribution, Levisticum officinale, morphology, phenology, rust fungi

Submitted 23 September 2019. Published 31 October 2019

Тихоненко Ю.Я., Гайова В.П. 2019. Перші знахідки Puccinia bornmuelleri (Pucciniales) в Україні. Украӥнський ботанічний журнал, 76(5): 445-450.

Інститут ботаніки ім. М.Г. Холодного НАН України

вул. Терещенківська 2, Київ 01004, Україна

Реферат. Новий для України іржастий гриб Pисcinia bornmuelleri був зареєстрований на Levisticum officinale на садових ділянках у двох селах Київської області у червні 2019 року. Цей гриб вперше був зібраний Й. Борнмюллером у 1892 році на території Ірану і описаний П. Магнусом у 1899 році. До кінця 20-го століття він був відомий лише 3 Ірану та Афганістану, але з 2000 року він відмічається в Центральній Європі. На сьогодні цей гриб зареєстрований в Австрії, Нідерландах, Німеччині, Польщі, Румунії, Угорщині, Україні (це повідомлення), Фінляндії та Чехії. Очевидно, недавня поява цього виду в Європі пов'язана зі змінами клімату. Дані про поширення P. bornmuelleri до 21-го століття свідчать на користь гіпотези, що природний ареал L. officinale обмежується територією Ірану та Афганістану. Дослідження під сканувальним електронним мікроскопом виявили, що шипики на поверхні урединіоспор розташовані переважно у їхній верхній частині. Відмічена цікава фенологічна особливість гриба, а саме розвиток молодих спермогоніїв і первинних урединіїв у першій декаді вересня, що свідчить про здатність теліоспор проростати без періоду зимового спокою, оскільки спермогонії можуть розвиватися лише після зараження рослини базидіоспорами. Стаття ілюстрована оригінальними мікрофотографіями, отриманими за допомогою світлового і сканувального електронного мікроскопів.

Ключові слова: іржасті гриби, морфологія, поширення, фенологія, Levisticum officinale

(C) 2019 Yu.Ya. Tykhonenko, V.P. Hayova. Published by the M.G. Kholodny Institute of Botany, NAS of Ukraine. This is an open access article under the terms of the Creative Commons Attribution License (http://creativecommons.org/licenses/by/4.0/), which permits use, distribution, and reproduction in any medium, provided the original work is properly cited 


\section{Introduction}

Puccinia bornmuelleri Magnus parasitizes Levisticum officinale W.D.J. Koch which is currently a single species in the genus Levisticum Hill. The fungus was first collected by J. Bornmüller on $L$. persicum Freyn \& Bornm. (= L. officinale) in Persia (now Iran) in 1892 and later was described by P. Magnus (1899). After that, the species was not observed elsewhere until 1962, when it was recorded in Afghanistan (Petrak, 1966). Thus by the end of the $20^{\text {th }}$ century, P. bornmuelleri was only known from these two countries. However, starting from 2000 onwards, the fungus has been observed in several countries within Central Europe. At first, in 2000 it was reported in Romania (Tănase et al., 2007), then since 2006 - in the Czech Republic (Müller, Šafránková, 2007) and Poland (Wołczańska, Wójciak, 2010), since 2007 - in Austria (Plenk, Bedlan, 2009; RieglerHager, 2011) and 2010 - in Germany (Ruske, Dörfeld, 2011). In 2017 the fungus was found in the Netherlands (Boomsluiter, 2018). Moreover, images of the infected leaves and fungal spores from additional two countries are currently available on the internet: from Finland (https://aphidcluster.tumblr.com/post/146318476191/ puccinia-bornmuelleri-rust-fungus-on-lovage/amp) and Hungary (e.g. Plant Parasites of Europe, 20012019).

The aim of this publication is to report the first records of $P$. bornmuelleri in Ukraine and to provide some data on its morphology and life cycle.

\section{Materials and methods}

Infected leaves of $L$. officinale were collected in garden plots in Bodenky and Dudarkiv villages (Kyiv Region, Ukraine). The specimens were studied under a dissecting microscope, labelled and dried for further treatment. Uredinio- and teliospores mounted in water or lactic acid were examined by light microscopy. Photomicrographs were taken under a Primo Star microscope, Canon A300 digital camera and AxioVision 4.7 software, used as well for measurements of microstructures. For scanning electron microscopy, samples were covered with an ultrathin coating of gold by ion beam sputtering unit JFC-1100. Images were obtained by a scanning electron microscope JEOL JSM-6060 LA.

The specimens are deposited in the Mycological Herbarium of the M.G. Kholodny Institute of Botany, National Academy of Sciences of Ukraine (KW-M).

\section{Results and discussion}

Epiphytotic development of rust disease of lovage was recorded in June-September 2019 in two districts of Kyiv Region. Morphological features of uredinial and telial stages of the collected specimens match those of P. bornmuelleri. A diagnosis and original illustrations of the species, data on its morphology and phenology are provided below.

Puccinia bornmuelleri Magnus, Verh. K. K. Zool.Bot. Ges. Wien 49: 94. 1899.

Spermogonia mainly hypophyllous on discoloured spots with slightly raised margins, honey-yellow, submerged, spherical or slightly flattened, $100-140 \mu \mathrm{m}$ in diameter (Fig. 1, B, C). Primary uredinia (uredinoid aecia in ontogenetic terms) mostly hypophyllous, first appear as surrounding spermogonia, and later directly below them, $1.5-3 \mathrm{~mm}$ in diameter, round, usually confluent into lesions of up to $4 \mathrm{~mm}$ long causing deformation of host tissue, cinnamon brown, pulverulent. Secondary uredinia develop as a result of re-infection by urediniospores, usually smaller than primary ones and cause less deformation of host tissue (Fig. 1, A). Urediniospores broadly ellipsoidal, broadly obovate to spherical, often tapered or rounded in the basal part, $29-35 \times 23-26 \mu \mathrm{m}$, light brown wall, about $2 \mu \mathrm{m}$ thick, thickened to $4-5 \mu \mathrm{m}$ at the top, spiny; the spines decrease from the apex downward, so that the base of the spore is almost bald (Fig. 1, D; 2, A-C); germ pores $2-3$, equatorial. Telia arise from both primary and secondary uredinia, round, $0.25-1.0 \mathrm{~mm}$, blackbrown (Fig. 1, A), sometimes confluent, on petioles up to $8 \mathrm{~mm}$ long. Teliospores clavate, ellipsoid to almost oblong, 35-44 × 20-26 $\mu \mathrm{m}$, slightly constricted at the septum, downward tapered or rounded, covered with undulate ridges, chestnut-brown, germ pore of the upper cell apical, without or with a flat papilla, in the lower cell in its lower third; pedicel short, colorless, spores deciduous (Fig. 1, E, F; 2, D-F).

Distribution in Ukraine. On Levisticum officinale W.D.J.Koch: Kyiv Region, Vyshhorod District, Bodenky village, garden plot, $50^{\circ} 50^{\prime} \mathrm{N}, 30^{\circ} 43^{\prime} \mathrm{E}$, 14.06.2019 (KW-M71268), 15.06.2019 (KW-M71269), 21.06.2019 (KW-M71272), 28.06.2019 (KW-M71273), 02.07.2019 (KW-M71274), 09.07.2019 (KW-M71275), 23.07.2019 (KW-M71276), 07.08.2019 (KW-M71278), 07.09.2019 (KW-M71279), 08.09.2019 (KW-M71280), leg. Yu.Ya. Tykhonenko; Boryspil District, Dudarkiv village, garden plot, $50^{\circ} 26^{\prime} \mathrm{N}, 30^{\circ} 56^{\prime} \mathrm{E}, 19.06 .2019$ (KW-M71270, KW-M71271), 03.08.2019 (KW-M71277), 20.09.2019 (KW-M71281), leg. V.P. Hayova. 


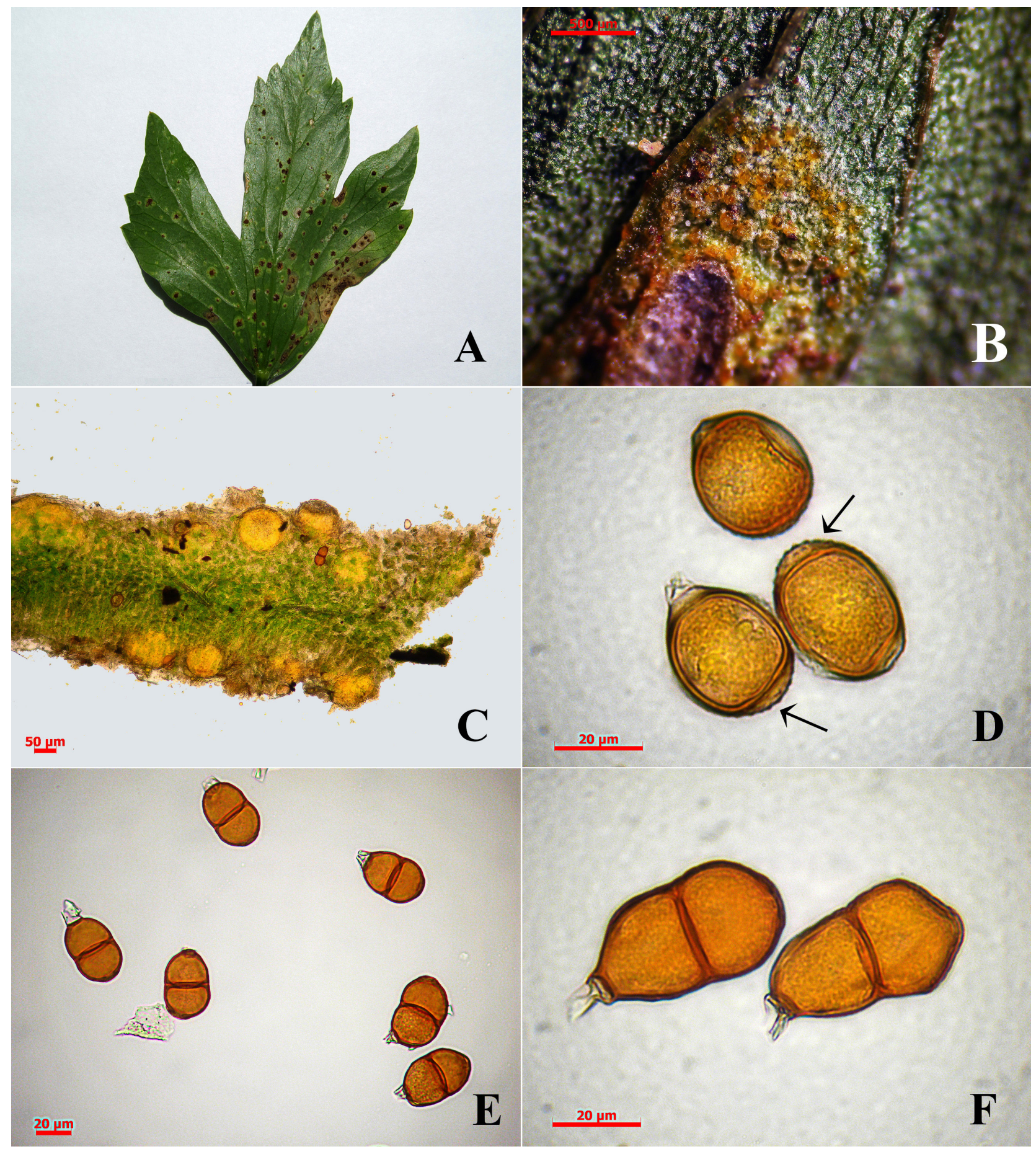

Fig. 1. Puccinia bornmuelleri on Levisticum officinale (LM). A: habit of uredinia and telia on abaxial surface of leaf. B: spermogonia on underside of leaf collected 07.09.2019; C: cross-section of spermogonia; D: urediniospores. Note equatorial germ pore in upper urediniospore and thicker-walled echinulate apical part in each of the other two urediniospores (arrows); E: general view of teliospores; F: two teliospores with pedicel remnants. Note wall ornamentation with undulate ridges and apical germ pore of the upper cell in the teliospore on the right. Bars: $500 \mu \mathrm{m}$ (B), $50 \mu \mathrm{m}(\mathrm{C}), 20 \mu \mathrm{m}(\mathrm{D}-\mathrm{F})$ 


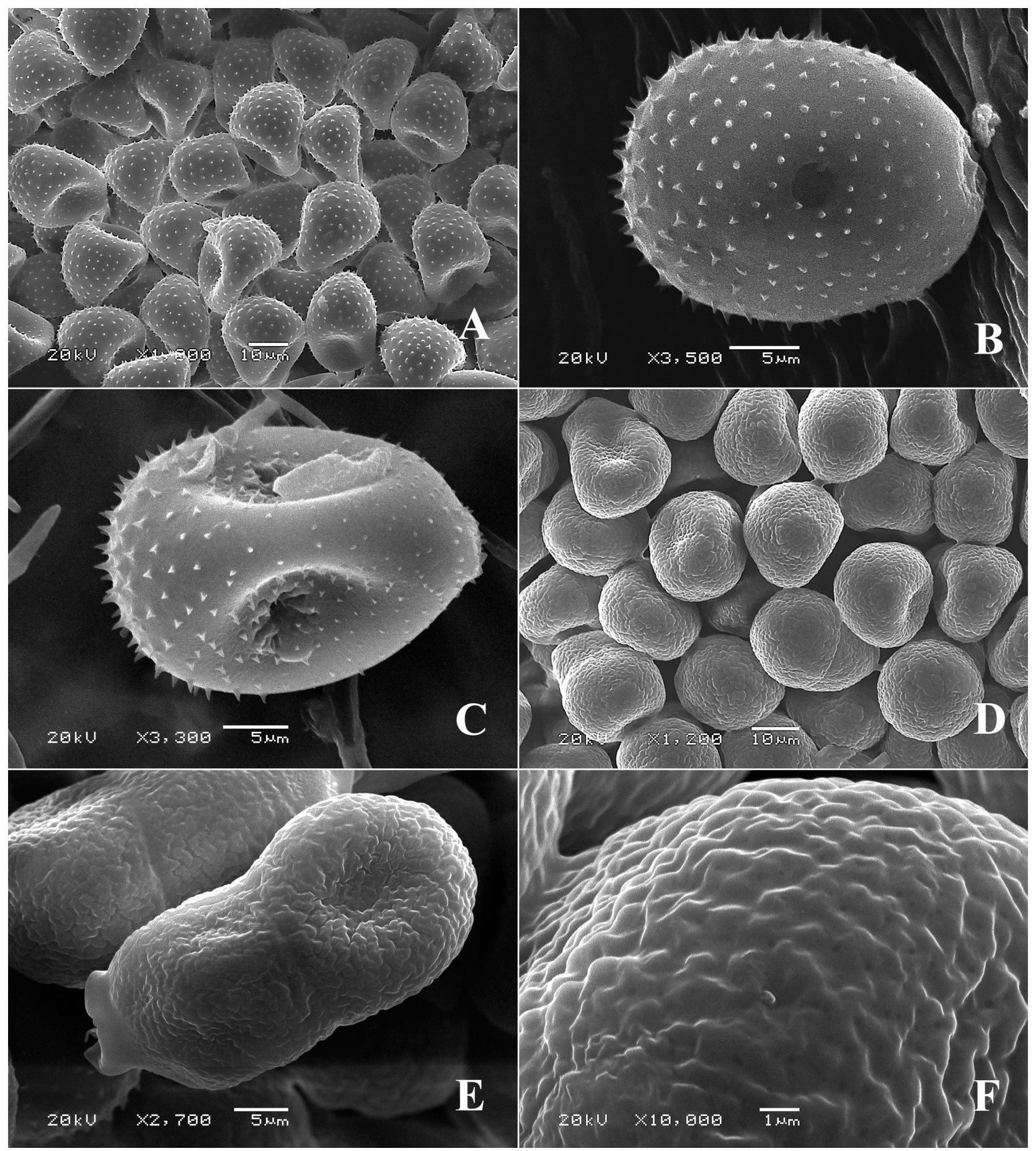

Fig. 2. Puccinia bornmuelleri on Levisticum officinale (SEM). A: urediniospores inside uredinium; B, C: urediniospores with one equatorial germ pore visible (B) and two germ pores (C). Note more echinulate apical part and almost smooth basal part of urediniospores. D: teliospores inside telium; E: two-celled teliospore with remnants of short pedicel; F: wall ornamentation of teliospore. Bars: $10 \mu \mathrm{m}(\mathrm{A}, \mathrm{D}), 5 \mu \mathrm{m}(\mathrm{B}, \mathrm{C}, \mathrm{E}), 1 \mu \mathrm{m}(\mathrm{F})$ 
General distribution. Europe: Austria, Czech Republic, Finland, Germany, Hungary, the Netherlands, Poland, Romania, Ukraine. Asia: Afghanistan, Iran.

Puccinia bornmuelleri is a brachycyclic autoecious species confined to $L$. officinale. Brachycyclic species of Puccinia parasitizing plants of the Apiaceae family, apart from the same type of their life cycle, possess some common morphological features. Their urediniospores have three equatorial germ pores and a cell wall thickened at the apex, while teliospore surface is glabrous, verrucose or covered with ridges, in contrast to reticulate-pitted wall ornamentation of teliospores in macrocyclic species of Puccinia on Apiaceae. By these features $P$. bornmuelleri undoubtedly belongs to the former group. However, species of these two groups of Puccinia may have urediniospores with similar ornamentation, for example not uniformely echinulate wall surface. As shown by our study under SEM, urediniospores in $P$. bornmuelleri are lacking spines on their basal regions (Fig. 2, B, C). Therefore they are somewhat similar in their wall ornamentation to those of $P$. conii (F. Strauss) Fuckel, a species associated with Conium maculatum L. Teliospores in $P$. bornmuelleri are ornamented with undulated ridges which are most apparent under SEM (Fig. 2, E, F) and thus they also bear some resemblance to those in $P$. conii. At the same time, teliospores in P. bornmuelleri are quite similar in appearance to those in $P$. opopanacis Ces. and $P$. phymatospora Lindr., parasitizing Opopanax chironium (L.) W.D.J.Koch and Selinum silaifolium (Jacq.) Beck, respectively. Relations between the mentioned species of fungi could be resolved properly only by molecular phylogenetic research.

The native range of the host plant, $L$. officinale, is disputed. Some sources argue that it originally comes from the eastern Mediterranean (Anderberg, Anderberg, 2000), others consider the species as native only to Iran and Afghanistan and therefore regard European populations as naturalized (Blamey, GreyWilson, 1989). Data on the narrow distribution range of $P$. bornmuelleri before the $21^{\text {st }}$ century give evidence in favor of the latter hypothesis. The recent spread of this fungus and its range expansion across Europe, in our opinion, could be explained by the rise in the average temperature of the Earth's climate system.

In the life cycle of $P$. bornmuelleri, teliospores begin to develop a few days after urediniospores start dissemination (Dörfelt, Ruske, 2011). In our observations, abundant teliospores were also produced very early, shortly after initial formation of urediniospores, so that telia completely replaced uredinia over a short period in summer. This might suggest that teliospores can germinate without overwintering. Moreover, we noticed freshly emerged spermogonia in the first decade of September on the late summer offshoots of lovage (Fig. 1, B, C). Occurrence of spermogonia in the life cycle of this fungus has been reported in late April-early May (Dörfelt, Ruske, 2011). Our observations in mid-September, apart from spermogonia, revealed primary uredinia on the same leaves of young shoots of the examined host plants. Development of both these stages in early autumn was probably triggered by a very dry and hot late summer in 2019 followed by low rainfall. However, since spermogonia can only originate from basidiospore infection, these observations support the hypothesis that teliospores in P. bornmuelleri can germinate without being exposed to freezing temperatures.

In conclusion, our study provides some previously unknown data on morphology and phenology of P. bornmuelleri, a newly reported rust fungus in Ukraine. Observations by SEM led to more information about surface ornamentation of urediniospores, in particular revealed not uniform wall surface of urediniospores with echinulations restricted mostly to their upper areas. Furthermore, a distinct for rust fungi phenology was recorded when mature spermogonia and primary uredinia were found on the infected plants in early autumn rather than the following spring. Thus, our observations suggest that teliospores of this fungus can germinate without overwintering. Further surveys are required to gather information on the distribution and phenology of this fungus. Finally, since $P$. bornmuelleri is an autoecious species completing its life cycle on L. officinale, it can rapidly spread across large areas where the host plant is cultivated or naturalized.

\section{Acknowledgements}

We are grateful to Prof. V.P. Heluta for his valuable advices and to A.V. Terebilenko, a staff member of the M.G. Kholodny Institute of Botany NASU, for her assistance in scanning electron microscopy.

\section{REFERENCES}

Anderberg A., Anderberg A.L. 2000. Den virtuella floran. Elektronisk publikation, Naturhistoriska riksmuseet, Stockholm. Available at: http://linnaeus.nrm.se/flora/ di/apia/levis/levioff.html (Accessed 17 September 2019). 
Blamey M., Grey-Wilson C. 1989. Illustrated Flora of Britain and Northern Europe. London: Hodder \& Stoughton, 544 pp.

Boomsluiter M. 2018. Nieuwe soorten paddenstoelen in 2017. Kijk op Exoten, 23: 6.

Dörfelt H., Ruske E. 2011. Studien zum Entwicklungszyklus des Rostpilzes Puccinia bornmuelleri. Boletus, 33(1): 35-44.

Magnus P. 1899. J. Bornmüller. Iter Persico-turcicum 1892/93. Fungi. Pars II. Ein Beitrag zur Kenntnis der Pilze des Orients. Verhandlungen der KaiserlichKöniglichen zoologisch-botanischen Gesellschaft in Wien, 49: 87-103.

Müller J., Šafránková I. 2007. Occurrence of Puccinia bornmuelleri Magnus in the Czech Republic. Acta Universitatis Agriculturae et Silviculturae Mendeleianae Brunensis, 55(2): 95-98.

Petrak F. 1966 (publ. 1968). Kleine Beiträge zur Ustilagineen- und Uredineenflora von Afghanistan und Pakistan. Sydowia, 20(1-6): 278-287.
Plenk A., Bedlan G. 2009. First report of Puccinia bornmuelleri on Levisticum officinale (lovage) in Austria. New Disease Reports, 20: 17.

Plant Parasites of Europe. 2001-2019. Available at: https:// bladmineerders.nl/parasites/fungi/basidiomycota/ pucciniomycotina/pucciniales/pucciniaceae/puccinia/ puccinia-bornmuelleri/ (Accessed 17 September 2019).

Riegler-Hager H. 2011. Erstnachweis von Puccinia bornmuelleri Magnus in Kärnten. Carinthia II, 201/121: 383-386.

Ruske E., Dörfelt H. 2011. Puccinia bornmuelleri - neu für Deutschland. Zeitschrift für Mykologie, 77(1): 61-70.

Tănase C., Gjærum H.B., Constantinescu O. 2007. Puccinia bornmuelleri on cultivated Levisticum. Mycologia Balcanica, 4: 75-76.

Wołczańska A., Wójciak H. 2010. First report of Puccinia bornmuelleri causing rust disease of lovage in Poland. New Disease Reports, 21: 13.

Recommended for publication by V.P. Heluta 